João Paulo Garrido Pimenta

Professor no Departamento de

História da Universidade de São Paulo
BARATA, Alexandre Mansur.

\section{Maçonaria, sociabilidade ilustrada e independência do Brasil (1790-1822).}

Juiz de Fora/São Paulo: Editora UFJF/Annablume/Fapesp, 2006. 338 p.

Maçonaria e independência são dois temas que, no Brasil, frequentemente caminham de mãos dadas. Por um lado, alguns laços entre historiografia acadêmica e historiografia maçônica foram suficientes para a consagração da visão mitificada de que, de algum modo, tudo de relevante no processo de separação política entre Brasil e Portugal passou pela atuação de organizações secretas, mal e comodamente definidas como "maçônicas"; por outro, visões não-especializadas sobre a história continuam a ser cativadas e seduzidas por uma suposta busca por explicar o inexplicável, o que confere perene prestígio ao segredo e ao mistério, conteúdos tradicionalmente inseparáveis da história da maçonaria.

0 aparecimento do livro de Alexandre Mansur Barata deve, portanto, ser saudado em uma dupla perspectiva: por um lado, contribui com vigor para a renovação dos estudos do processo de independência do Brasil que vêm se desdobrando, na historiografia especializada, pelo menos pelas últimas duas décadas; por outro, ilumina com lucidez um tema ainda pouco conhecido e que, graças aos esforços dos historiadores - com o quê o nome de Barata se alinha a outros como os de Célia Azevedo, Marco Morel, Eliane Colussi, Luiz Véscio e Eliane Silva - surge cada vez mais destituído de atributos míticos.

Maçonaria, sociabilidade ilustrada e independência do Brasil (17901822) é resultado de tese de doutorado defendida na Universidade Estadual de Campinas em 2002, e representa um desdobramento coerente da trajetória intelectual de seu autor. Professor do Departamento de História do Instituto de Ciências Humanas da Universidade Federal de Juiz de Fora, Barata publicara em 1999 um estudo - também fruto de pesquisa acadêmica - sobre a maçonaria na passagem do Império à República (Luzes e sombras: a ação da maçonaria brasileira, 1870-1910. Campinas, EdUnicamp). Agora, sua atenção se concentra nos primeiros momentos da maçonaria na América portuguesa (em torno de 1790) e seu desenvolvimento pari passu com as grandes transformações ocorridas na passagem do século XVIII ao XIX, isto é, em meio ao processo de criação de condições para a independência do Brasil (em 1822). No entanto, os objetivos do autor não direcionam a compreensão da maçonaria e de seus membros pelo foco exclusivo da independência - o que forçosamente implicaria em reeditar uma modalidade de história que Barata supera com consciência e segurança. 0 problema que enquadra o tema está no surgimento e desenvolvimento de espaços de sociabilidade, onde, como bem sabemos hoje, são engendradas muitas das fundamentais transformações em curso no mundo ocidental daquele momento.

Nas palavras do próprio autor, a obra busca responder algumas questões centrais: "qual o sentido do pertencimento a esse tipo de sociabilidade? Como a maçonaria recrutava os seus membros e quais as suas principais formas de atuação? 0 que era ser maçom no final do século XVIII e início do século XIX no Brasil? Como se deu a inserção da sociabilidade maçônica na América portuguesa? Como as autoridades portuguesas viam o cres- 
cimento da maçonaria?" (p.29). Para respondê-las, a obra está divida em quatro capitulos. 0 primeiro, "Libertinos, afrancesados e pedreiros-livres", analisa o ambiente luso-americano de finais do século XVIII favorável à instalação e ao desenvolvimento preliminar da maçonaria; em linhas gerais, trata-se de um ambiente de alargamento de espaços públicos de discussão política - cada vez mais esquadrinhados pela historiografia recente - em meio aos quais surgem aquilo que Barata denomina de "manifestações heterodoxas", isto é, de crítica, em variados graus, ao estado de coisas vigente no mundo do Antigo Regime. 0 segundo, "Construindo templos às virtudes e masmorras aos vícios...", persegue o perfil de um indivíduo maçom no mundo luso-americano, os elementos que the conferem identidade, o imaginário social em torno dele e suas formas de associação, as quais permitirão, em pouco tempo, atuações difusas mas bastante contundentes no campo da política. 0 terceiro, "A coroa, a cruz e o esquadro", trata das relações entre maçonaria, Igreja e Estado, mostrando a politização das sociedades secretas por meio da repressão a elas. E finalmente, o último, "Rasgando o véu dos mistérios: os maçons em cena pública", aborda mais especificamente a atuação do chamado "Grande Oriente do Brasil" e que, às vésperas e durante a independência, assume a direção geral das lojas maçônicas no Brasil.

Ao longo destes capitulos, o que se revela ao leitor é uma forma de organização coletiva fluida, dinâmica e contraditória, permeada por diferentes referências, imagens e identidades, vista de maneira igualmente fluida por aqueles que, no auge da crise de dissolução do Império Português na América, com ela se preocuparam, por ela se interessaram ou nela se engajaram. A correta percepção de Barata no tocante ao seu caráter de espaço de sociabilidade - o que, no mundo luso-americano da passagem do século XVIII ao século XIX, geralmente é sinônimo também de politização - permite que o leitor, em meio a páginas bem escritas, amparadas em ampla bibliografia condizente com a abrangência ocidental do fenômeno em questão, e fundamentadas em rica e vívida documentação, se veja plenamente convencido da tese central do livro, exposta pelo autor já na sua "Introdução": "para além de uma identificação simplista entre Maçonaria-Independência[...], a sociabilidade proporcionada pelas lojas maçônicas contribuiu para a construção e mobilização das diversas forças sociais, não só como canal de divulgação do ideário liberal, mas, sobretudo, como espaço de construção de uma cultura política marcada pela prática do debate, da representação, da elaboração de leis, da substituição do nascimento pelo mérito como fundamento da ordem social e política, constituindo-se, portanto, em esteio para a criação de uma esfera pública civil, fundamental dentro do contexto social do mundo luso-brasileiro" (p.30).

É interessante notar que, por meio desta tese, Barata, para além de engrossar e refinar substantivamente nosso conhecimento do periodo em questão, aponta para um futuro que, na sua própria obra até o momento publicada, representa um hiato, e que cobre, aproximadamente, o Período Regencial e o Segundo Reinado até a década de 1870. Uma história da maçonaria que se encontra apenas esboçada em Luzes e sombras (p.6568), e cuja importância parece agora reiterada por Maçonaria, sociabilidade ilustrada e independência do Brasil. Suprimindo tal lacuna, é provável que o autor nos oferecesse uma espécie de "história geral" da maçonaria do Brasil, o que sem dúvida resultaria em obra importante, mas que, por 
outro lado, talvez significasse, em alguma medida, um retrocesso em relação à sua própria.

Explico. A única ressalva que faria a Maçonaria, sociabilidade ilustrada e independência do Brasil (1790-1822), reside em uma certa insistência do autor em, a despeito de suas formulações gerais e do desenvolvimento de seus argumentos centrais, manter a obra dentro de um enquadramento historiográfico que ele próprio nos indica como limitador; isto é, a considerá-la, ainda, como uma "história da maçonaria". Causa certo incômodo ler, por exemplo, as primeiras palavras de suas "Conclusões": "ao chegar ao fim deste trabalho, espero que ele tenha contribuido para que a história da Maçonaria, nos anos de sua inserção no Brasil, fosse melhor conhecida" (p.251). A maçonaria é, formalmente, ponto de partida e de chegada de Barata, mesmo que, para o leitor, seu livro seja muito mais do que isso. Trata-se, contudo, de questão menor. Uma maçonaria com muitas luzes e poucas sombras, portanto um amplo contexto histórico, crucial para a formação do Brasil independente, igualmente iluminado: eis o que, de modo geral, nos oferece esta obra, e eis no quê reside seu caráter definitivo.

Recebido para publicação em setembro de 2007 Aprovado em setembro de 2007 